\title{
WHICH ASPECTS OF THE ENGLISH LANGUAGE DO DISTANCE LEARNERS FIND DIFFICULT?
}

\author{
Dr. George Boon Sai TEOH \\ School of Distance Education \\ University Sains Malaysia, Malaysia \\ Dr. Agnes Liau Wei LIN \\ School of Humanities \\ University Sains Malaysia, Malaysia \\ Kathy BELAJA \\ School of Distance Education \\ University Sains Malaysia, Malaysia
}

\begin{abstract}
This study reports the findings of a research carried out on distance learners at the School of Distance Education (SDE), University Sains Malaysia (USM). The study was explorative in nature with the purpose identifying the aspects of the English language which distance learners found difficult to learn. A quantitative survey questionnaire design was adopted. The sample consisted of 512 students out of 1028 students who enrolled in the JUE300 English II course responded. The data were analyzed using SPSS IBM version 19.0. The distance learners reported facing difficulties in the aspects of speaking, vocabulary, grammar, writing, spelling, pronunciation, reading and listening in descending order. In the case of the SDE distance learners, their level of proficiency prior to this course, their commitment and hours spent on studying the English language may have affected their perceptions and achievement in the course.
\end{abstract}

Keywords: Distance learners, English language, distance education, aspects of English, difficulties

\section{INTRODUCTION}

University Sains Malaysia (USM) pioneered distance education in Malaysia establishing the School of Distance Education (SDE) in 1971 (Idrus, 2007). The distance education programmes aim to produce more qualified degree holders in order to elevate the status of the country. The programs can be viewed as a second chance for the working adults in Malaysia to attain a higher education. White (2003) observed that distance language learning has evolved from the traditional print-based correspondence course, to courses delivered entirely online with extensive opportunities for interaction, feedback and support between teachers and learners, and among the learners themselves. Salleh (1999) clarified that in the SDE, USM distance education programmes, the students are equipped with self-instructional modules and other multimedia materials such as audio-video materials and slides. Students have to use the internet, listen to radio broadcasts and attend teleconferencing sessions at the numerous regional centres distributed throughout Malaysia.

Bahasa Malaysia is the main medium of instruction while the English language is one of the university courses which students need to pass in order to graduate. Depending on 
the level of proficiency the students have attained for their English prior to registering as students; the distance learners need to obtain the required English proficiency credit units to graduate (School of Distance Education Guidebook 2014/2015).

This paper deliberates on the JUE 300 English II course; which is an upper-intermediate course focusing on the further development of the students' four language skills (listening, speaking, reading and writing) and improving the students' grammar and vocabulary. This will equip the students with the knowledge and skills to communicate effectively in everyday activities as well as in academic and job situations. For the JUE 300 English II course, the students are provided with a module consisting of 10 units for their self-study. There are also five audio recorded lectures placed in the e-learning portal of the SDE, USM for the students to refer to at their convenience. There are also two slots of face-to-face sessions during the Intensive course. The students are assessed via coursework, continuous assessment and the final exam.

\section{LITERATURE REVIEW}

The study is guided by the theoretical underpinnings of Knowles (1973), Ellis (1994), Krashen (1994) and McGroarty (1996). Knowles (1973) highlighted that in andragogy; teachers need to understand the characteristics of adult learners. Adult learners require practical, relevant content, materials and activities that cater to their needs and interests and enable them to exhibit their skills and knowledge. Meanwhile, Ellis (1994) explained that second language acquisition is a complex process, involving many interrelated factors. The term 'Second language acquisition' (SLA) refers to the subconscious or conscious processes by which a language other than the mother tongue is learnt in a natural or a tutored setting. Ellis stressed that there are affective prerequisites to acquisition such as a positive orientation to speakers of the language. The amount of skills and knowledge, called competence, will be acquired through input, and certainly the initial production will not be very accurate. Next, the Affective Filter Hypothesis in Krashen's (1994) Monitor theory explains why some people acquire a second language while others cannot. According to Krashen, some learners may not receive enough input due to attitude, anxiety, a lack of self confidence and motivation. If a learner is anxious or fearful, has low motivation and self esteem, then the affective filter will be high thus hindering language acquisition. If the opposite is true, the affective filter will be low and thus enabling acquisition. Also, according to McGroarty (1996), attitude has cognitive, affective and conative components; the cognitive component focuses on the cognition and thoughts, the affective deals with emotions and the conative component determines how an individual acts on those thoughts and feelings.

McGroarty (1996) asserts that an individual's attitude involves his or her beliefs, emotional reactions and behavioral tendencies related to the object of the attitudes. Various researchers have also discussed the effects of the affective states of learners on their language learning process (Bailey, 1983 and Guiora, 1983). It is more challenging for distance learners to learn English via distance education than for students undergoing conventional classroom teaching and learning in the universities which is caused by the remoteness of the learning situation. This can mean isolation for the learner as there are communication difficulties for the students to communicate with their teachers. Teoh, Liau and Belaja (2010) identified five institutional reasons inducing difficulties in adult distance learners at the SDE in learning the English language via distance education. The institutional reasons included issues such as interaction, English Language Course, Course lecturer, Learning module and E-learning portal, audio and visual materials. To support the students in distance education programmes; Tait (2003) underscored that learner support in distance education needs to focus on students' engagement to enable them to pursue their degree successfully. Thus, research on distance learners' perceptions about language learning is important because it is practical to assume that their viewpoints have an effect on their learning and eventually their achievements. At present, not much 
is known about the aspects of the English language that distance learners experience when learning English at SDE, USM. Thus, this study fills the gap by addressing the following research question; which aspects of the English language do distance learners find difficult when studying their JUE 300 English II course at the SDE, USM. The findings would inform the School of Distance Education of her students' difficulties for reference so that SDE, USM can offer good learner support and put into place measures that can ameliorate the situation.

\section{METHODOLOGY}

\section{Participants}

In this study, the researchers employed convenience sampling as it includes the whole population of the JUE $\mathbf{3 0 0}$ English language learners. Convenience sampling is convenient and is the least costly in terms of time and money (Ferber, 1977). All JUE 300 students enrolled in the JUE 300 course totaling 1028 were invited to participate. JUE 300 is a level II course at SDE USM. A total of 512 students voluntarily returned complete questionnaires of this survey. The age range of participants is shown in Table 1.

Table: 1

Age Range of Participants

\begin{tabular}{ccl}
\hline Age range of participants & Frequency & Percent \\
\hline $20-30$ years & 138 & 27.0 \\
$31-40$ years & 289 & 56.4 \\
$41-50$ years & 72 & 14.1 \\
> 50 years & 13 & 2.5 \\
Total & 512 & 100.0 \\
\hline
\end{tabular}

\section{Instrument}

The questionnaire comprised three sections. The items in the first section consisted of eight aspects of the English language that learners might find difficult to learn, namely writing, speaking, reading, listening, pronunciation, grammar, spelling and vocabulary. In the second section, there were $\mathbf{1 6}$ items regarding various factors which can induce difficulty in learners to learn the English language via distance education. The third section comprised 31 items which relate to reasons learners might find language learning via distance education difficult. This paper only focuses on the aspects of the English language which the distance learners found difficult to learn via their distance education mode.

The eight aspects the distance learners were asked to identify as being difficult to learn were: (A1), speaking (A2), pronunciation (A3), reading (A4), grammar (A5), spelling (A6), listening (A7) and vocabulary (A8). Respondents indicated their response to each item based on a five-point Likert scale $(1=$ Strongly disagree; 2 = Disagree; $3=$ Neutral; 4 = Agree, and; 5 = Strongly Agree). The questionnaire was checked and validated by a senior lecturer with a PhD from the SDE, USM, who has many years of experience teaching the English language course through distance education. The purpose of validation is to ensure the contents in the questionnaire were suitable for the target research sample and was relevant to the research objectives.

\section{Procedure}

The questionnaires were distributed to the students of the course at the first JUE 300 English course lecture during the Intensive Course. The researchers clarified that participation in the study was voluntary and no extra course credits were given for participation. The researchers gave the participants sufficient time to complete the questionnaires. Students who were willing to participate were requested to return the questionnaires by the end of the Intensive Course. The students had approximately three weeks to complete and hand in the questionnaires. Collection boxes were prepared and were located at the main office and in 
front of the course lecturer's office to ensure convenience for learners to hand in the questionnaires.

\section{Data Analysis}

The data were analyzed using the SPSS IBM version 19.0. Internal consistency reliability is a measurement about whether the single test is consistent among the items as well as the whole test (Darren \& Malley, 2003). In this study, the Cronbach's alpha approach generated by SPSS was used to measure the reliability and suitability of questions in the questionnaire. As shown in Table 2, the overall Cronbach's alpha value for the aspects of the English language which distance learners found difficult was 0.870. Based on Table 3, the Cronbach's alpha value shows that the questionnaire is reliable (Darren \& Mallery, 2003).

Table: 2

Cronbach's Reliability Test Result

\begin{tabular}{lcc}
\hline Questionnaire & $\begin{array}{c}\text { Number } \\
\text { of Items }\end{array}$ & $\begin{array}{c}\text { Cronbach's Alpha } \\
\text { Coefficient }\end{array}$ \\
\hline $\begin{array}{l}\text { Aspects of English language which learners find } \\
\text { difficult }\end{array}$ & 8 & 0.870 \\
\hline
\end{tabular}

Table: 3

Description of Cronbach's Alpha Coefficient Reliability (Darren \& Mallery, 2003)

\begin{tabular}{ll}
\hline Cronbach's Alpha Coefficient & Description \\
\hline Alpha $>0.9$ & Very good \\
Alpha $>0.8$ & Good \\
Alpha $>0.7$ & Accepted \\
Alpha $>0.6$ & Questionable and accepted \\
Alpha $>0.5$ & Weak and accepted \\
Alpha $>0.4$ & Not accepted \\
\hline
\end{tabular}

\section{RESULTS AND DISCUSSION}

Table 4 shows the aspects of the English language that distance learners found difficult to learn via the distance education mode at SDE, USM.

Table: 4

Aspects of the English language learners found difficult

\begin{tabular}{|c|c|c|c|c|}
\hline Item & Questions & $\mathbf{N}$ & $\boldsymbol{\mu}$ & SD \\
\hline A1 & fficult to write in English. & 502 & 3.27 & 0.926 \\
\hline A2 & lish. & 502 & 3.45 & 0.909 \\
\hline A3 & I am not able to pronounce any English word correctly. & 501 & 3.16 & 0.918 \\
\hline A4 & $\begin{array}{l}\text { I cannot understand the contents of any } \\
\text { book/notes/article/newspaper in English when I read it. }\end{array}$ & 500 & 2.84 & 0.869 \\
\hline A5 & I fare badly in sentence making because of my poor grammar. & 502 & 3.35 & 0.861 \\
\hline A6 & I have a lot of spelling mistakes in my writing. & 502 & 3.23 & 0.941 \\
\hline A7 & $\begin{array}{l}\text { I cannot understand what others say when they speak in } \\
\text { English. }\end{array}$ & 502 & 2.65 & 0.904 \\
\hline A8 & $\begin{array}{l}\text { I find it difficult to express what I want to say because of my } \\
\text { limited vocabulary. }\end{array}$ & 500 & 3.41 & 0.927 \\
\hline
\end{tabular}

$\mathbf{N}=$ number of respondents, $\mu=$ mean, $\mathrm{SD}=$ standard deviation 
By using the mean value 1.00 to 1.49 to represent strongly disagree, 1.50 to 2.49 to represent disagree, 2.50 to 3.49 to represent neutral, 3.50 to 4.49 to represent agree and 4.50 to $\mathbf{5 . 0 0}$ to represent strongly agree; the results showed that generally respondents depicted a neutral stand for the items listed. By ranking the mean values of the items (as shown in Table 5); it is evident that speaking, vocabulary and grammar are the three main aspects of the English language learners find difficult to learn. This is followed by writing, spelling, pronunciation, reading and listening in descending order.

Table: 5

Ranking of the Aspects of the English Language that Learners Found Difficult

\begin{tabular}{llll}
\hline Rank & Item & Aspects & Mean \\
\hline 1 & A2 & Speaking & 3.45 \\
2 & A8 & Vocabulary & 3.41 \\
3 & A5 & Grammar & 3.35 \\
4 & A1 & Writing & 3.27 \\
5 & A6 & Spelling & 3.23 \\
6 & A3 & Pronunciation & 3.16 \\
7 & A4 & Reading & 2.84 \\
8 & A7 & Listening & 2.65 \\
\hline
\end{tabular}

The data show the following:

$>47.5 \%$ of the students reported a response of strongly agree and agree to Item A2: I cannot speak fluently in English;

$>45.35 \%$ of the students reported a response of strongly agree and agree to Item A8: I find it difficult to express what I want to say because of my limited vocabulary;

$>41.1 \%$ of the students reported a response of strongly agree and agree to Item A5: I fare badly in sentence making because of my poor grammar;

$>35.3 \%$ of the students reported a response of strongly agree and agree to Item A1: I find it difficult to write in English;

$>\mathbf{3 8 . 2} \%$ of the students reported a response of strongly agree and agree to Item A6: I have a lot of spelling mistakes in my writing;

$>35.1 \%$ of the students reported a response of strongly agree and agree to Item A3: I am not able to pronounce any English word correctly.

$>\mathbf{2 0 . 0 \%}$ of the students reported a response of strongly agree and agree to Item A4: I cannot understand the contents of any book/notes/article/newspaper in English when I read it.

$>15.9 \%$ of the students reported a response of strongly agree and agree to Item A7: I cannot understand what others say when they speak in English.

Overall, the results show that the distance learners at SDE USM reported facing most difficulties in the aspects of speaking, vocabulary and grammar while learning the English Language via distance education at SDE USM. The distance learners felt that it was most difficult to improve their fluency in speaking English. They mentioned that it was difficult for them to express themselves due to their limited vocabulary. This is not surprising as Jilg and Southgate (2014) observed that in distance language learning, distance learners generally do not have many chances to improve their productive skills - especially speaking English in authentic real life contexts with native or good speakers of English.

The level of difficulty reported by the distance learners appears to be almost at a neutral level. There may be some students who experienced higher levels of difficulties as they were working adults who have just returned to studying English after a break from formal studies. 
McGroarty (1996) noted that formal language study does not necessarily improve the students' perceptions towards the target language. It depends very much on the duration of study, the quality and context of teaching and learning. In the case of the SDE distance learners, their level of proficiency prior to this course, their commitment and hours spent on studying the English language could very much influence their perceptions as well as their performance in this course. This might be compounded by the nature of distance learning where the students were not able to gain access to the target language environment which would have facilitated their learning of the language. Additionally, the JUE 300 English course students at the SDE, USM were only provided with the JUE 300 English course module consisting of 10 units for their self-study. They were encouraged to access the self-instructional modules and other multimedia materials such as audiovideo materials, slides, materials from the internet at their convenience. There were only five audio recorded lectures placed in the e-learning portal of the SDE, USM which the distance learners might or might not access depending on their own initiatives. Also, there were only two slots of face-to-face sessions during the Intensive course for the students to seek clarifications from the course lecturer. These challenges that the distance learners face in a distance learning context may hamper their development of autonomous learning. (Hurd, Beaven \& Ortega, 2001).

In their context, the language lecturer was mostly not physically present to correct and guide these students in their process especially in terms of spoken English as compared to traditional classroom settings. White (1999) termed this as working in isolation with minimal access to course lecturers. Moreover, most of the distance learners were working adults; thus, these students might not have adequate time to focus on learning English effectively as they have to study for their major subjects too. As Murphy (2008) explained although distance learners are supposed to be autonomous learners; not all the students will succeed to learn autonomously.

In the search of an effective language teaching approach for distance learners; researchers, designers and instructors dealing with the teaching of English language to adult distance learners need to keep in mind Knowles' (1973) principles in andragogy in that these adult learners have characteristics which vary in terms of different cultures, learning histories and experiences.

In addition, as stressed by Ellis (1985), second language acquisition is a complex process, involving many interrelated factors. Hence, course designers and instructors must be aware of the individual differences that play a significant role in the learning of a language. Especially in the distance learning second language learning contexts such as SDE USM; the students have many differences in terms of age, gender, language learning history, type of occupation, expectations and peer influences which invariably influence language learning attitudes and achievement. The large class size of the JUE $\mathbf{3 0 0}$ English II course (approximately 1000 - 1200 students each academic year) also affects the interaction of the students with the course lecturers during their limited face-to face encounter and also in terms of the lecturer responding to the students' emails and phone calls.

As highlighted by Krashen (1994) the affective states of learners are equally influential in determining the success of learners in absorbing inputs in learning English. McGroarty (1996) also stressed that attitude has cognitive, affective and conative components; which decide the actions taken by an individual based on his/her beliefs and feeling. In the case of the SDE USM learners, it is important that their feedback about their difficulties be understood and resolved so that they do not develop a negative attitude towards learning the English course. In order to reduce the difficulties faced by the students, the students should be guided to improve their writing, reading and listening skills via encouraging them to look up particular suggested websites which can assist 
them. Students' spelling and pronunciation abilities should also be enhanced by instructing them to look up the various dictionaries available online. Students should be exposed to the various appropriate materials and teaching techniques available so that they can choose those that suit them best. If students are supported to cultivate a positive perception on learning English, they will hopefully invest more time and effort to learn the language which will influence the student's language development rate and success.

\section{CONCLUSION}

The distance learners in this study highlighted that speaking, vocabulary and grammar as aspects they found especially difficult when it comes to learning the English language in the present situation. Based on these findings, the authors would like to make the following recommendations for designers and instructors of language learning courses in distance education: The course designers should 1) be aware of the particular needs of the distance learners especially in terms of speaking 2) increase the number of contact hours via teleconferencing sessions or traveling to regional centres to meet the students and create opportunities for students to learn, interact and seek answers to their queries in the target language 3) guide and motivate the students to spend sufficient time on reading and enriching their vocabulary as well as on practicing their communication skills and learning grammar.

In the quest to improve the teaching of English language to distance learners; teachers would do well to understand the background and characteristics of their students. They need to understand the students' difficulties, perceptions and environments. Students' affective state towards the language and their achievement depends very much on conditions of study and the quality of teaching and support provided. Course designers and instructors for English language teaching and learning via distance education should strive to design and develop courses which attend to these concerns. They have to ensure that the quality and context of teaching is not compromised due to the distance education mode. They need to make sure that the English language course is deemed useful, worthwhile and relevant to the students not only in terms of passing the course but also for the learner to participate in other meaningful interactions using the language and for their self-improvement, academic and professional pursuits. Better teaching materials, strategies and environment can reduce negative perceptions about the various aspects of English that students view as difficult and eventually help the students to improve and achieve success.

\section{BIODATA and CONTACT ADDRESSES of the AUTHORS}

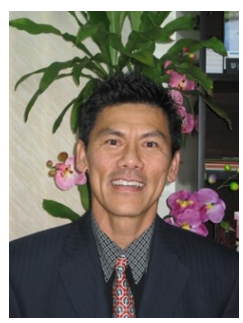

Dr. George Boon Sai TEOH is a senior lecturer teaching English and Distance Education at the School of Distance Education, University Sains Malaysia. For his PhD, George conducted research concerning Emotional Intelligence at the University of Cambridge, United Kingdom. His research area comprises Emotional Intelligence, Distance Education, English Language teaching and learning as well as Health and Fitness.

\footnotetext{
Dr. George Boon Sai TEOH, School of Distance Education, Universiti Sains Malaysia, 11800 Minden, Penang, MALAYSIA Phone: +604 6532275, Fax: +604657 6000, Email: georgeteoh@usm.my
} 


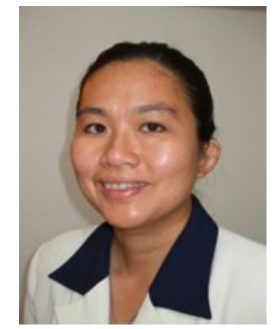

Dr. Agnes Liau Wei LIN is a senior lecturer teaching English Literature and Research Methods at the School of Humanities, University Sains Malaysia. She obtained her BA and MA degrees from University Malaya in the field of English Literature. For her PhD, Agnes studied at the University of Cambridge, UK. Her areas of research interests encompass the Teaching and Learning of Literature in English in Malaysian schools as well as the idea of Race, Religion and aspects of Philosophy in literary texts.

\author{
Dr. Agnes Liau Wei LIN \\ School of Humanities, \\ Universiti Sains Malaysia, \\ 11800 Minden, Penang, MALAYSIA, \\ Phone : +604 6533338, \\ Fax: +6046563707 , \\ Email: agnes@usm.my
}

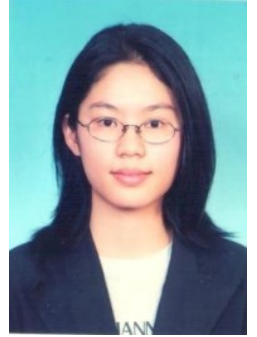

Kathy BELAJA is a former postgraduate candidate at the School of Distance Education, University Sains Malaysia, Malaysia. Kathy's MA research was on the Effects of Lecturer's Transactional Presence towards Learners' Intrinsic Motivation in Learning English as a Second Language through Distance Education. A part of her research findings has been published in Volume 14. No. 1 of the Malaysian Journal of Distance Education in 2012.

Mrs. Kathy BELAJA

School of Distance Education, Universiti Sains Malaysia, 11800 Minden, Penang, MALAYSIA,

Phone: +6046532275

Fax: +6046576000 ,

Email: kathybelaja@gmail.com

\title{
REFERENCES
}

Bailey, K. (1983). Competitiveness and anxiety in adult second language learning: Looking at and through the diary studies. In H.W. Selinger \& M.H. Long (Eds.), Classroom-oriented research in second language acquisition (pp. 67-103). Rowley, Mass.: Newbury House.

Baker, C. (1993). Foundation of bilingual education and bilingualism. Clevedon: Multilingual Matters.

Brown, H. D. (2000). Principles of language learning and teaching. New York: Pearson.

Darren, G. \& Mallery, P. (2003). SPSS for windows step by step; A simple guide and reference (4th ed.). Boston: Pearson Education.

Ellis, R. (1994). The study of second language acquisition. Oxford: Oxford University Press.

Ferber, R. (1977). Research by convenience. The Journal of Consumer Research, 4(1), 57 $-58$.

Guiora, A.Z. (1983). The dialectic of language acquisition. Langauge Learning, 33, 3-12.

Hurd, S., Beaven, T. \& Ortega, A. (2001) Developing autonomy in a distance language learning context: Issues and dilemmas for course writers. System, 29(3), 341-355. 
Idrus, R. M. (2007). Technogogy: A convergence of pedagogy, technology and content in distance education. Penang, Malaysia: School of Distance Education, Universiti Sains Malaysia (USM).

Jilg, T. \& Southgate, M. (2014): Students helping students: A learning partnership initiative for distance language learners, The Language Learning Journal, DOI: 10.1080/09571736.2013.877067

Knowles, M. S. (1973). The adult learner: A neglected species. Houston, TX: Gulf.

Krashen, S. (1994). The input hypothesis and its rivals. In N. Ellis (Ed.) Implicit and explicit learning of languages. London: Academic Press.

McGroarty, M. (1996). Language attitudes, motivation and standards. In S. McKay, \& Hornberger, N. (Eds.) Sociolinguistics and language teaching, pp. 3-46. Cambridge: Cambridge University Press.

Murphy, L., (2008) Supporting learner autonomy: Developing practice through the production of courses for distance learners of French, German and Spanish. Language Teaching Research, 12, 1 (pp 83-102.)

School of Distance Education Guidebook 2013/2104 (2013). Penang: School of Distance Education, Universiti Sains Malaysia.

Salleh, M. N. (1999). The evolution of science technology usage at the Universiti Sains Malaysia distance learning programme. The Malaysian Journal of Distance Education, $1(1), 5-16$.

Tait, A., \& Mills, R. (Eds.). (2003). Rethinking learner support in distance education. London: Routledge Falmer.

Teoh, B. S., Liau, W. L., \& Belaja, K. (2010). Five institutional reasons adult distance learners find it difficult to learn the English language via distance education. The Malaysian Journal of Distance Education, 12 (2), 15-31.

White, C.J. (1999) Expectations and emergent beliefs of self-instructed language learners. System, $27(4), 443-457$.

White, C.J. (2003). Language learning in distance education. Cambridge, United Kingdom: Cambridge University Press. 